\title{
Contribution of solvents from road marking paints to tropospheric ozone formation
}

\author{
Tomasz E. Burghardt ${ }^{1}$, Anton Pashkevich ${ }^{2}$, Lidia Żakowska ${ }^{2}$ \\ ${ }^{1}$ M. Swarovski GmbH, Industriestrasse 10, 3300 Amstetten, Austria, \\ e-mail tomasz.burghardt@swarco.com \\ ${ }^{2}$ Politechnika Krakowska im. Tadeusza Kościuszki, ul. Warszawska 24, 31-155 Kraków, \\ e-mailapashkevich@pk.edu.pl,lzakowsk@pk.edu.pl
}

\begin{abstract}
Solventborne road marking paints are meaningful sources of Volatile Organic Compounds (VOCs), which under solar irradiation affect formation of tropospheric ozone, a significant pulmonary irritant and a key pollutant responsible for smog formation. Influence of particular VOCs on ground-level ozone formation potential, quantified in Maximum Incremental Reactivities (MIR), were used to calculate potential contribution of solvents from road marking paints used in Poland to tropospheric ozone formation.

Based on 2014 data, limited only to roads administered by General Directorate for National Roads and Motorways (GDDKiA), emissions of VOCs from road marking paints in Poland were about $494838 \mathrm{~kg}$, which could lead to production of up to $1003187 \mathrm{~kg}$ of tropospheric ozone.

If aromatic-free solventborne paints based on ester solvents, such as are commonly used in Western Europe, were utilised, VOC emissions would not be lowered, but potentially formed ground-level ozone could be limited by $50-70 \%$. Much better choice from the perspective of environmental protection would be the use of waterborne road marking paints like those mandated in Scandinavia - elimination of up to $82 \%$ of the emitted VOCs and up to $95 \%$ of the potentially formed tropospheric ozone could be achieved.
\end{abstract}

Keywords: road marking, waterborne paint, solventborne paint, tropospheric ozone, VOC, road safety, MIR, environmental protection.

\section{Background}

Horizontal road markings are essential safety feature on all modern roads. They are quite frequently in the centre of drivers' attention, providing information about the lateral positioning of the vehicle and give guidance during driving.

The markings in Poland are generally divided into two types: thick-layer $(1 \mathrm{~mm}$ or thicker), comprising thermoplastic and coldplastic masses, and thin-layer (less than $1 \mathrm{~mm}$ ) comprising various paints with a possibility of using coldsprayplastic as well. Coldplastics and thermoplastics shall not be covered in this analysis as they are considered solvent-free. Plural-component systems based on epoxy or urethane technologies, which can be either solventborne, water-dispersible, or solvent-free are not discussed, either. Properties of waterborne and solventborne paints and their application characteristics were described elsewhere [1].

Solventborne paints used for horizontal road markings are a meaningful source of VOC emissions, which are capable of increasing the level of tropospheric ozone. Herein, we estimated the amounts of VOCs emitted from road marking paints used in Poland and calculated potential of the ozone formation from these VOCs. To demonstrate alternatives, 
the simulation was extended to include aromatic-free paints such as are at present used in Western Europe and waterborne paints, which are the only type permitted in Scandinavia.

A notable limitation of our work is that only paints used for marking of roads administered by GDDKiA were included - only about $19000 \mathrm{~km}$ (out of $\sim 250000 \mathrm{~km}$ of the total public paved roads network) due to difficulty of obtaining data from a plenitude of sources. In our preceding work on this topic, we have concentrated on the city of Kraków and demonstrated that road marking paints contribute to air pollution in that ecological disaster area $18254 \mathrm{~kg}$ of VOCs that could be adding up to $42350 \mathrm{~kg}$ of tropospheric ozone [2].

The results of this analysis can be used by road administrators as an aid in selection of road marking materials that are environmentally-friendly. Simultaneously, paint formulators are being made aware that emissions of VOCs are not all equal.

\subsection{Composition of road marking systems}

Typical road marking paints consist of an organic polymeric resin (binder), inorganic pigments and fillers, a package of additives, and a blend of organic solvents (for waterborne paints - mostly water). Classes of their components, with particular attention paid to solvents, are discussed below.

\subsubsection{Binders}

Modern solventborne road marking paints are based on $100 \%$ acrylic binders. The binders are produced by polymerisation of monomers like methyl acrylate, methyl methacrylate, ethyl acrylate, butyl acrylate, and similar. The resulting polymeric material is a solid readily soluble in numerous organic solvents. Solventborne paints dry by simple evaporation of solvents, which leaves a film consisting of the pigments and dried binder.

Waterborne paints are also based on 100\% acrylic binders forming their polymeric backbone. However, with the development of quick-set technology, the polymeric chains were modified to contain monomers with moieties capable of acid-base chemistry [3]. Additionally, binders for waterborne paints, which always are delivered in aqueous solutions, require a base to assure protonation of the acidic moieties and a surfactant to keep the polymer suspended.

Modern waterborne paints furnish surprisingly quick drying and their application does not require special equipment or knowledge, except normally expected differences associated with novel technology. A weakness of waterborne paints is washout resistance time, which occurs after drying: A sudden rain on freshly applied waterborne paint may dissolve it if the washout resistance time was not reached. Another weakness is slowing of drying at marginal application conditions combining low temperature and high humidity. Quick-set waterborne paints dry and cure due to simultaneous physical and chemical changes. They are typically more durable than comparable solventborne paints, as we have measured and recently reported [2].

\subsubsection{Pigments and fillers}

All white paints contain titanium dioxide. Even in yellow or blue paints, small amount of titanium dioxide is included to give clean shades. Production of titanium dioxide is quite complex. Titanium dioxide can be produced by chlorine or by sulphate process; comparison of cradle-to-grave Life Cycle Assessment (LCA) for these processes demonstrated that either one is very harmful for the environment, albeit in different aspects [4]. Indeed, an LCA of road marking materials has shown that titanium dioxide, despite its quite low content, is the third major environmental impactor, lesser only than the impacts caused by the production of binder and glass beads [5]. Surface treatment of titanium dioxide typically 
consists of inorganic and organic chemicals and can vary greatly between grades and manufacturers; it plays profound role in stability of waterborne road marking paints.

Amongst eight known titanium dioxide polymorphs, two are of importance: rutile and anatase. In paints, rutile is used, because it has higher refractive index: 2.7 , as compared to only 2.5 for anatase. In titanium dioxide crystal structure, each titanium atom is surrounded by six oxygen atoms in octahedral arrangement with mostly regular structure. In more closely packed rutile structure, the octahedra are turned through $90^{\circ}$ with a twist of $45^{\circ}$ from one layer to the next. In anatase, the twists are missing, which negatively influences packing and was reported to reduce the refractive index. Anatase is occasionally added to paints to improve their durability and lower raw materials expense.

Of course, to prepare colours other than white, appropriate organic pigments are used. In some cases, a small amount of inorganic colour pigments like iron oxide is also added to achieve the desired paint properties.

Majority of the volume of paint is calcium carbonate - readily available harmless inexpensive filler. Some paints, especially those designed for special purposes, can also contain other fillers. Paints ought to be devoid of any pigments or fillers containing chromium, lead, or other heavy metals.

\subsubsection{Additives}

Amongst other raw materials for paint production, there is a plethora of additives, which are necessary to assure paint processing and stability. Appropriate selection of additives plays the most profound role in all paints and is quite frequently the major differentiator between equivalent formulations from different manufacturers.

Amongst additives, dispersants, most of the time based on functionalised acrylates, play critical role not only in proper dispersing of pigment particles, but also in preventing their flocculation and settling.

In-can stability is achieved by the use of thickeners and anti-settling additives, which prevent separation of pigment particles from the binder and their precipitation. Organic and inorganic, naturally-derived and engineered compounds are available and suitable.

Defoamers are used to release any air bubbles formed during paint processing and application. For road marking paints, it is critical that the defoamers remain compatible with glass beads, which meaningfully limits their selection.

Plasticisers that assure appropriate flexibility of the dried film are frequently added as some paints might be too brittle to withstand impact caused by tyres and snow ploughs. It is important that phthalate-free plasticisers are utilised, because of environmental and health concerns.

For waterborne paints, one additionally can use biocides, surfactants, wetting agents, grinding aids, and other materials. However, the most important is coalescent: With the current technology, it is not possible to prepare a successful waterborne paint without a coalescent or an alternate molecule that acts as such. Coalescents are small molecules that "bring together" drying polymeric chains and thus furnish smooth crack-free surface.

\subsubsection{Solvents}

Solvents are necessary to make the paint liquid. Amongst the numerous available materials, paint manufacturers select only a few that show the desired properties, like speed of evaporation, capability of penetration of the surface cracks to improve durability and adhesion of the paint, and price. Selected properties of solvents commonly used in road marking paints are given in Table 1 and their chemical structures are provided in Fig. 1. Solubility parameters describing a sphere of solubility, based on like-dissolves-like principle, were 
developed by Hansen and bear his name [6]. The sphere can be used to predict solubility of different materials - in case of road marking paints such information is needed to properly dissolve the binder and simultaneously to prepare paints with good adhesion to bituminous and concrete surfaces.

Toluene is a commonly used aromatic solvent; its moderate evaporation rate is advantageous in prevention of forming skin and essentially uniform dry-through of the forming film. Toluene has very high dispersion forces solubility parameter $(\delta \mathrm{d})$, which along with low polarity $(\delta p)$ and low hydrogen bonding capability $(\delta \mathrm{H})$ gives it the capability of penetrating surface cracks and even dissolving some of typical oily contaminations present on road surface. Hence, the use of toluene is favoured by the paint formulators and applicators. However, toluene is quite harmful for the environment and as such it is effectively banned in Western Europe. In Poland, its amount is limited to $8 \%$ of the total road marking paint formulation [7]. Toluene is not a carcinogen [8], but it is classified as reproductive toxicant and targets organs like kidneys, liver, and the central nervous system. Due to its solubility in lipids, absorption through dermal exposure is as likely as inhalation and equally harmful. A recent field assessment of road marking crews' exposure to toluene has shown that the permissible concentrations were not exceeded [9].

Other common solvents, either esters or ketones, generally are somewhat more polar and are capable of better forming hydrogen bonding. Hence, while their capability of dissolving acrylic resin is not affected, they are somewhat less likely to penetrate surface cracks and adhere to oily asphalt. Their evaporation rates depend on the carbon chain length and functionality, so selection of appropriate blends to achieve paint dry-through without skin formation is quite easy. Generally, ester solvents are considered in the industry as better, due to their lower toxicity and good affinity for resins.

Acetone, with an exceptionally high evaporation rate and high solubility parameters is barely suitable for road marking paints, because excessively fast drying of the paint would prevent good adhesion, particularly when road surface temperatures are high. However, acetone has miniscule toxicity and its ozone formation potential is so low that it is considered in the United States an 'exempt solvent', not counted as VOC [10].

Table 1. Properties of selected solvents commonly used for road marking paints

\begin{tabular}{lcccccc}
\hline \multirow{2}{*}{ Name } & $\begin{array}{c}\text { Density } \\
{\left[\mathrm{g} / \mathrm{cm}^{3}\right]}\end{array}$ & $\begin{array}{c}\text { Evaporation } \\
\text { rate }^{(\mathrm{a})}\end{array}$ & $\begin{array}{c}\text { Boiling } \\
\text { point }\left[{ }^{\circ} \mathrm{C}\right]\end{array}$ & \multicolumn{3}{c}{ Hansen solubility parameters ${ }^{(\mathrm{b})}$} \\
\cline { 8 - 10 } Toluene & 0.87 & 200 & 110 & 18.0 & $\delta \mathrm{d}$ & $\delta \mathrm{H}$ \\
\hline 1-methoxypropan-2-yl acetate & 0.97 & 33 & 146 & 15.6 & 5.6 & 9.8 \\
\hline Butyl acetate & 0.88 & 100 & 126 & 15.8 & 3.7 & 6.3 \\
\hline Methyl isobutyl ketone & 0.80 & 166 & 116 & 15.3 & 6.1 & 4.1 \\
\hline Methyl ethyl ketone & 0.81 & 390 & 80 & 16.0 & 9.0 & 5.1 \\
\hline Acetone & 0.79 & 560 & 56 & 15.5 & 10.4 & 7.0 \\
\hline
\end{tabular}

(a) Relative to $n$-butyl acetate, assumed as 100. (b) Hansen solubility parameters are given in the units of $\mathrm{MPa}^{1 / 2}: \delta \mathrm{d}$ denotes dispersive forced, $\delta \mathrm{p}-$ dipolar intermolecular forces, and $\delta \mathrm{H}$ - hydrogen bonding.

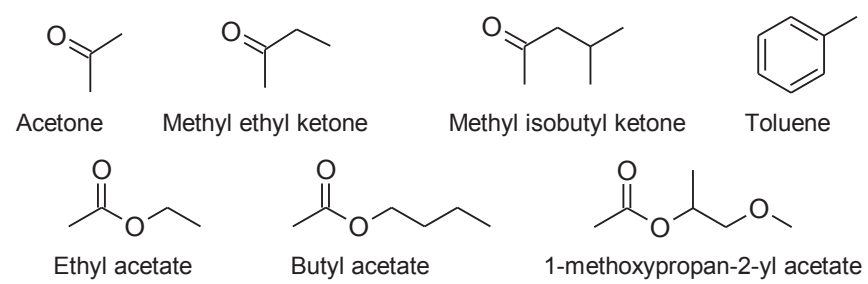

Fig. 1. Chemical structures of common solvents 
Properties of volatiles present in waterborne road marking paints are given in Table 2: water is the main solvent. Water, with its slow evaporation, would normally translate to very slowly drying paints; fortuitously, modern waterborne paints employ another drying and curing mechanism, which permits for their exceptionally quick drying [3]. The same mechanism allows for application of films reaching even $1200 \mu \mathrm{m}$ without unacceptable slowing of drying [1].

Amongst the volatiles, one must list ammonium hydroxide, which is the base necessary to keep the paints stable before application, decomposes to ammonia, which quickly evaporates upon application, causing drop in $\mathrm{pH}$ and thus paint drying and curing. Ammonia is an irritant, so several commercial ammonia-free binders have been devised; unfortunately, these binders do not permit yet to achieve the desired quick drying of applied road marking. A small amount of ethyl alcohol is added to the paint as a processing aid and also to augment freeze-thaw stability.

Another volatile, albeit evaporating extremely slowly, is Texanol ${ }^{\circledR}$, a $\mathrm{C} 12$ hydroxyesters mixture that acts as coalescent. Chemical structure of Texanol ${ }^{\circledR}$ is provided in Fig. 2; the ratio of the two esters is not disclosed by either the original manufacturer (Eastman Chemical, of Kingsport, Tennessee, U. S. A.) or numerous makers of generics.

Table 2. Properties of volatile materials used for waterborne road marking paints

\begin{tabular}{|c|c|c|c|c|c|c|}
\hline \multirow{2}{*}{ Name } & \multirow{2}{*}{$\begin{array}{l}\text { Density } \\
{\left[\mathrm{g} / \mathrm{cm}^{3}\right]}\end{array}$} & \multirow{2}{*}{$\begin{array}{c}\text { Evaporation } \\
\text { rate }^{(\mathrm{a})} \\
\end{array}$} & \multirow{2}{*}{$\begin{array}{c}\text { Boiling } \\
\text { point }\left[{ }^{\circ} \mathrm{C}\right]\end{array}$} & \multicolumn{3}{|c|}{ Hansen solubility parameters ${ }^{(\mathrm{b})}$} \\
\hline & & & & $\delta \mathrm{d}$ & $\delta \mathrm{p}$ & $\delta \mathrm{H}$ \\
\hline Ammonium hydroxide & 0.73 & $\mathrm{n} / \mathrm{a}$ & 37 & $\mathrm{n} / \mathrm{a}$ & $\mathrm{n} / \mathrm{a}$ & $\mathrm{n} / \mathrm{a}$ \\
\hline Ethanol & 0.79 & 165 & 78 & 15.8 & 8.8 & 19.4 \\
\hline Texanol $^{\circledR}$ & 0.95 & 0.002 & 255 & 7.4 & 3.0 & 4.8 \\
\hline Water & 1.00 & 30 & 100 & 7.6 & 7.8 & 20.7 \\
\hline
\end{tabular}

(a) Relative to $n$-butyl acetate, assumed as 100. (b) Hansen solubility parameters are given in the units of $\mathrm{MPa}^{1 / 2}: \delta \mathrm{d}$ denotes dispersive forced, $\delta \mathrm{p}$ - dipolar intermolecular forces, and $\delta \mathrm{H}-$ hydrogen bonding.

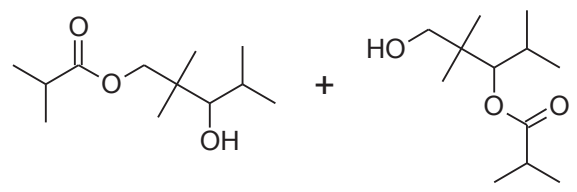

Fig. 2. Chemical structure of Texanol ${ }^{\circledR}$

\subsubsection{Glass beads}

Glass beads are used as reflective elements and are inalienable component of road marking systems. Beads of various refractive indices and sizes ranging in diameter from about $100 \mu \mathrm{m}$ to $2 \mathrm{~mm}$ are commonly used. Incorporation of anti-skid particles in glass beads packages assures proper skid resistance, necessary for safety during wet conditions.

The selection of glass beads is critical to achieve the optimum performance of the applied systems as they not only provide retroreflectivity, but also protect the paints from abrasion caused by the vehicular traffic. Appropriate embedment of glass beads is necessary to achieve retroreflectivity [11], so the application crews must adjust the beads flow to obtain the best results. Mismatch between glass surface coating and the road marking paint can lead to significant lowering of beads-paint adhesion, causing premature failures.

High-performance glass beads can furnish very high retroreflection, which can exceed $1000 \mathrm{mcd} / \mathrm{m}^{2} / \mathrm{lx}$ while the required initial minimum is only $200 \mathrm{mcd} / \mathrm{m}^{2} / \mathrm{lx}$. Numerous reports demonstrate positive impression from people who drive on roads with high retrore- 
flectivity of the horizontal markings [12][13], even though some reports show no direct correlation between retroreflectivity and road safety [14]. Definitely, elderly drivers benefits from higher retroreflection [15]. It is also very likely that the improved aesthetics associated with clear and well-marked roads would lead to increased safety [16][17].

\subsection{Tropospheric ozone}

Ozone, a tri-molecular allotrope of oxygen, is naturally occurring and forms in the atmosphere during lightning. Majority of ozone is found in the lower stratosphere, where it plays critical role in absorption of ultraviolet rays and thus protection of life on Earth. However, ozone is also present in the troposphere. Some of it is a result of natural atmospheric mixing, but majority has been reported to be formed as a result of photolytic decomposition of nitrogen oxide $\left(\mathrm{NO}_{2}\right)$, according to a general scheme shown in eq. 1 [18].

(Step) Reaction Reaction rate

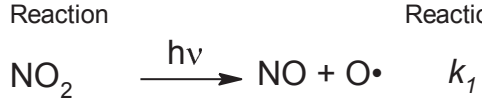

$$
\begin{aligned}
& \mathrm{O} \cdot+\mathrm{O}_{2} \longrightarrow \mathrm{O}_{3} \quad k_{2} \\
& \mathrm{NO}+\mathrm{O}_{3} \longrightarrow \mathrm{NO}_{2}+\mathrm{O}_{2} \quad k_{3}
\end{aligned}
$$

In eq. 1, steps (1) and (2) lead to ozone generation, while step (3) accounts for ozone depletion. Hence, equilibrium shown in eq. 2 forms.

$$
\left[\mathrm{O}_{3}\right]=\frac{\left[\mathrm{NO}_{2}\right] k_{1}}{[\mathrm{NO}] k_{3}}
$$

Ozone is one of the key components of smog. It is a severe respiratory system irritant; its negative effects on human health are well-documented [19] and numerous premature deaths are attributed to its presence at the ground level [20]. Concerning is the fact that higher concentration of ozone in cities lead to prolonged and repeated exposure of people who are already exposed to a plethora of other pollutants, which might exaggerate its harmfulness. Even though Poland does not suffer from tropospheric ozone pollution as extreme as, for example, Northern Italy, the concentrations are still sufficiently high to cause damage to certain sensitive plants [21].

\subsection{Maximum Incremental Reactivity (MIR)}

All of the VOCs undergo decomposition in the atmosphere via photolytic pathways, as was first reported by Leighton [22]. Elucidation of the mechanism and confirmation that the VOCs affect the equilibrium shown in eq. 2 was done by Crutzen [23]. Laboratory experiments and theoretical calculations have demonstrated very significant differences between ozone formation that could be attributed to various VOCs, as was reported by Carter and Atkinson [24]. The differences are caused by chemical moieties formed during decomposition, which in can be re-introduced times into the ozone formation reactions.

VOC-influenced ozone formation depends on many factors, such as concentrations in the above-defined equilibrium, presence of other pollutants, temperature, irradiation level, etc. To quantify these effects, Carter defined maximum incremental reactivity as "the amount of additional ozone formation resulting from the addition of a small amount of the compound to the system in which ozone is formed, divided by the amount of compound 
added" and devised for California Air Quality Management District a straightforward protocol and a measurement scale [25]. The conditions used by Carter assume the worst-case scenario of high insolation ( $35^{\circ}$ North) and unlimited $\mathrm{NO}_{2}$ supply. The studies were later examined and confirmed by several researchers [26]; field measurements of pollution plumes further confirmed the theoretical and laboratory analyses [27]. Subsequent adjustments of the calculated and published MIR values were done as new data and methodologies became available [28], but the general trends remain in force.

\section{Results and discussion}

\subsection{Methodology}

The use of MIR, which are expressed in the unit of grams of potentially formed ozone per gram of VOC made the calculations very simple and straightforward [25]. MIR values published in California Code of Regulations, Title 17, Chapter 8, $\$ 94700$ were used.

To perform the calculations, results from a query for public information to GDDKiA were analysed [29]. The response provided the surface area that was painted and in some cases also the specific paint: in 2014, $3436371 \mathrm{~m}^{2}$ was marked. To obtain the mass amount, an assumption of a typical thin-layer application of $600 \mathrm{~g} / \mathrm{m}^{2}(400 \mu \mathrm{m})$ wet film was made, yielding paints consumption of $2061822 \mathrm{~kg}$. Amongst other necessary assumptions, in cases where multi-year contracts were in force, the provided amounts were divided by the number of years to give an approximate annual usage. In some cases, where the specific paint was not listed, solvent composition being a weighted average of other paints was used.

The solvents compositions were taken from publically available Safety Data Sheets. To avoid providing excessive data details that would obscure the main point of our work, we have analysed the solvents compositions and combined them into two categories: toluene plus esters and toluene plus ketones. The solvent packages were idealised, because the Safety Data Sheets do not list exact compositions and chromatographic analyses for positive solvents identification was beyond the scope of our work.

\subsection{Solvent compositions and emissions}

Composition of the volatiles from these two paints categories and alternative paints are shown in Table 3. It should be noted that the compositions of solventborne paints are somewhat different as used for model paints in case of our paper concentrating on Kraków [2], because of the aforementioned approximation.

For our calculations, all of the paints were assumed to contain $24 \%$ of solvents, which upon application evaporate to become VOCs. In case of waterborne paint, the VOC were assumed to be $5 \%$, with the remaining $19 \%$ being water. Considerations regarding VOC of the coalescent were discussed elsewhere [2].

In Table 4 are listed the data obtained from GDDKiA regarding the painted surfaces, which we broke down based on the paints composition [29]. Aromatic-free and waterborne paints were not listed amongst ordered by applicators. Total emitted VOCs and the calculated maximum amounts of formed tropospheric ozone based on the MIR are provided. 
Table 3. Idealised composition of volatiles of the analysed paints and their MIR

\begin{tabular}{lccccc}
\hline Solvent & MIR & Toluene - ketones & Toluene - esters & Esters & Waterborne \\
\hline Toluene & 4.00 & $8.0 \%$ & $8.0 \%$ & & \\
\hline Methyl isobutyl ketone & 3.88 & $8.0 \%$ & & & \\
\hline Methyl ethyl ketone & 1.48 & $8.0 \%$ & & & \\
\hline Butyl acetate & 0.83 & & $8.0 \%$ & $12.0 \%$ & \\
\hline Ethyl acetate & 0.63 & & $8.0 \%$ & $8.0 \%$ & \\
\hline 1-methoxypropan-2-yl acetate & 1.70 & & & $4.0 \%$ & \\
\hline Texanol ${ }^{\circledR}$ & 0.81 & & & $0.5 \%$ \\
\hline Ethanol & 1.53 & & & $1.0 \%$ \\
\hline Ammonium hydroxide & 0.00 & & & $19.0 \%$ \\
\hline Water & 0.00 & & & \\
\hline
\end{tabular}

Table 4. Tender data from GDDKiA: solvents compositions and emissions

\begin{tabular}{lcc}
\hline Solvents package: & Toluene - ketones & Toluene - esters \\
\hline Marking area $\left[\mathrm{m}^{2}\right]$ & 547985 & 2888386 \\
\hline Paint amount $[\mathrm{kg}]$ & 328791 & 1733032 \\
\hline Maximum ozone $[\mathrm{kg}]$ formed per $1 \mathrm{~kg}$ of paint & 0.749 & 0.437 \\
\hline Maximum ozone $[\mathrm{kg}]$ formed per painted $1 \mathrm{~m}^{2}$ & 0.449 & 0.262 \\
\hline Total emitted VOC $[\mathrm{kg}]$ & 78910 & 415928 \\
\hline Total potentially formed tropospheric ozone $[\mathrm{kg}]$ & 246199 & 756988 \\
\hline
\end{tabular}

As shown in Table 4, the amount of potentially produced ozone very significantly exceeds the emitted VOCs in all cases, mostly because of high MIR of toluene and methyl isobutyl ketone. The paints containing ketone solvents are meaningfully less environmentally friendly as compared to those where esters are used. Fortunately for our environment, the paints containing ketones appear to be less popular amongst applicators.

In case of paints that contain toluene and ketone solvents, up to $0.749 \mathrm{~kg}$ of groundlevel ozone could be formed from each kilogram of paint applied $\left(0.449 \mathrm{~kg}\right.$ per $1 \mathrm{~m}^{2}$ of painted surface). At annual use of $328791 \mathrm{~kg}, 78910 \mathrm{~kg}$ of VOCs are emitted to the atmosphere, which could lead to the formation of up to $246199 \mathrm{~kg}$ of tropospheric ozone. With paints where esters are used along toluene, the ozone formation potential is lower, at $0.437 \mathrm{~kg}$ per $1 \mathrm{~kg}$ of paint $\left(0.262 \mathrm{~kg}\right.$ per $1 \mathrm{~m}^{2}$ of marked surface). Therefore, the annual usage of $1733032 \mathrm{~kg}$ translates to VOC emissions of $415928 \mathrm{~kg}$ and potentially up to $756988 \mathrm{~kg}$ of tropospheric ozone produced.

Overall, from the annual thin-layer marking of roads administered by GDDKiA, approximately $494838 \mathrm{~kg}$ of VOCs are emitted to the atmosphere, leading to potential formation of up to $1003187 \mathrm{~kg}$ of ozone.

The supply of $\mathrm{NO}_{2}$ necessary for ozone formation is furnished directly at the road marking application sites by vehicular traffic - traffic jams caused by marking activities do increase the $\mathrm{NO}_{2}$ availability. Measurements correlating vehicular traffic, nitrogen oxides concentration, and tropospheric ozone were reported over 20 years ago [30].

Insolation in Poland ( $50^{\circ}$ North) is meaningfully lower as compared to the conditions used for obtaining MIR ( $35^{\circ}$ North), which is a significant abating factor making the above maxima unlikely to be reached in our country. Furthermore, extreme temperatures are not frequent and meaningful part of road marking is done either after sunset or in autumn when the insolation is nil or marginal. However, one has to remember that even if the solvents do not decompose in the troposphere and not cause increased ozone formation, they migrate to stratosphere, where they cause more harm to the environment. 


\subsection{Environmentally-friendly alternatives}

One of our goals was presenting readily available alternatives to the currently used systems. Hence, solvent packages of a toluene-free ester-based solventborne road marking paint and a waterborne paint were included in Table 3 . We do not include a "0 VOC" paint according to the United States rules, because such paint, despite very low impact on the formation of tropospheric ozone [31], would be a poor alternative on our roads and could be prohibitively expensive.

In Table 5, we are providing results for the same volumes of paints that were ordered for road marking by GDDKiA, but assuming two readily available alternatives: Aromaticfree ester-based solventborne paint and a waterborne paint. The savings of our natural resources could be enormous, as visualised in Fig. 3, where various emissions scenarios are compared. Assuming that only ester solvents were used (without toluene or methyl isobutyl ketone), the amount of potentially formed ozone could be lowered by approximately 50 $71 \%$. Limiting the emissions of VOC by $82 \%$ and lowering potential of tropospheric ozone formation by $83-95 \%$ could be achieved if all thin-layer marking were done with a waterborne paint.

Table 5. Emissions from alternative paints

\begin{tabular}{lcc}
\hline Solvents package: & Esters & Waterborne \\
\hline Maximum ozone $[\mathrm{kg}]$ formed per 1 kg of paint & 0.218 & 0.036 \\
\hline Maximum ozone $[\mathrm{kg}]$ formed per painted $1 \mathrm{~m}^{2}$ & 0.131 & 0.022 \\
\hline Total emitted VOC $[\mathrm{kg}]$ in case of full conversion & 494837 & 87627 \\
\hline Total potential formed ozone $[\mathrm{kg}]$ in case of full conversion & 449447 & 74226 \\
\hline$\quad$ Potential of lowering VOC emissions & $0 \%$ & $-82 \%$ \\
\hline Potential for lowering tropospheric ozone formation & $-50 \%--71 \%$ & $-83 \%--95 \%$ \\
\hline
\end{tabular}

\section{EMITTED VOC AND POTENTIALLY FORMED OZONE}

(various solvent composition scenarios)

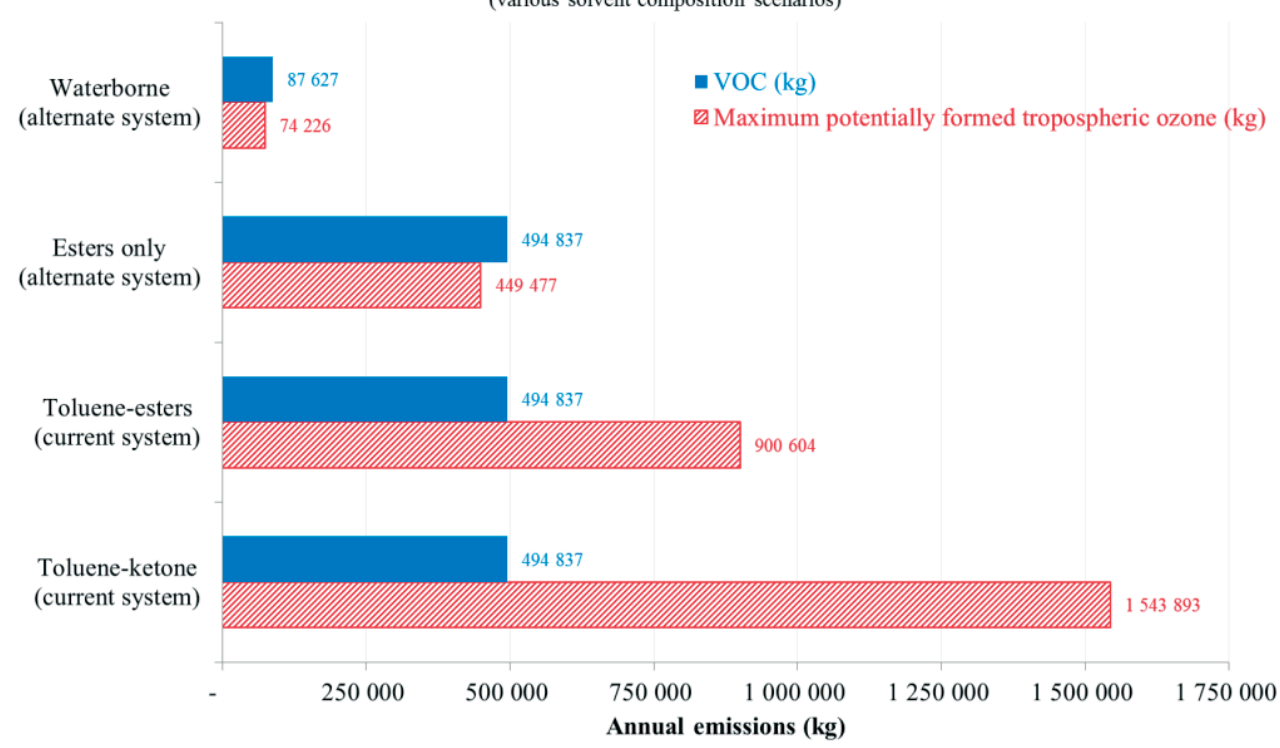

Fig. 3. Emissions scenarios with various solvent packages 


\section{Conclusions}

This analysis of road marking paints used in Poland has demonstrated profound influence of their solvent packages on tropospheric ozone formation potential. The calculations have shown that $2061823 \mathrm{~kg}$ of paints used for thin-layer markings of roads administered by GDDKiA emit to the atmosphere $494838 \mathrm{~kg}$ of VOCs capable of producing up to $1003187 \mathrm{~kg}$ of tropospheric ozone. While lowering the VOC emissions would require switch to a technology of waterborne paints, which is still a novelty in Poland, significant potential for tropospheric ozone formation could be achieved with simple adjustments of solvent blends within the existing technology. Solventborne paints with carefully selected solvents could lead to lowering of the potentially formed tropospheric ozone by about $50 \%$. However, better choice would be the use of waterborne paints, which emit up to $79 \%$ VOCs less and their solvents have ozone formation potential lower by $83-95 \%$.

The results provided herein do not include paints ordered by local road authorities. These amounts are significant, because local roads constitute about $90 \%$ of total paved roads in Poland. In fact, an environmental analysis report has estimated the use of solventborne road marking paints in Poland in 2006 at $21308000 \mathrm{~kg}$, with expected significant growth [32].

In comparison with other anthropogenic emissions, such as vehicular or industrial, pollution caused by road marking paints is insignificant. However, every little effort that can help our environment should not be abandoned, especially if more sustainable alternatives are readily available.

We have provided in this work a tool to road administrators in selecting environmentally-friendly sustainable solutions and simultaneously gave information to paint formulators to select materials with least impact on the health of our planet.

\section{References}

1 Babić D., Burghardt TE., Babić D. Application and Characteristics of Waterborne Road Marking Paint. International Journal for Traffic and Transport Engineering 5 (2015) 150-169.

2 Burghardt TE., Pashkevich A., Żakowska L. Influence of Volatile Organic Compounds Emissions from Road Marking Paints on Ground-Level Ozone Formation. Case Study of Kraków, Poland. Transportation Research Procedia (2016) in press.

3 Clinnin DD., Heiber WG., Lewarchik RJ. Fast dry waterborne traffic marking paint. United States Patent 5,340,870.

4 Reck E., Richards M. Titanium dioxide - Manufacture, environment, and life cycle analysis: The tioxide experience. Surface Coatings International 80 (1997) 568-572.

5 Kheradmand H. Life Cycle Assessment. Road Marking Technologies Eco-Profile. Intertraffic, Amsterdam, 2012.

6 Hansen CM. The three dimensional solubility parameter and solvent diffusion coefficient. Copenhagen, Denmark: Danish Technical Press (1967).

7 IBDiM (Instytut Badawczy Dróg i Mostów / Road and Bridge Research Institute). Warunki Techniczne. Poziome znakowanie dróg. POD-2006. Seria „I” - Informacje, Instrukcje. Warszawa, 2007.

8 McMichael AJ. Carcinogenicity of benzene, toluene and xylene: epidemiological and experimental evidence. IARC Scientific Publication 85 (1988) 3-18.

9 Szpakowska-Kozikowska E., Mniszek W. Exposure assessment of workers during road surface marking. Zeszyty Naukowe Wyższej Szkoły Zarządzania Ochroną Pracy w Katowicach 1 (2014) $32-40$.

10 Per United States Code of Federal Regulations, Chapter 40, $§ 51.100(\mathrm{~s})$. 
11 Grosges T. Retro-reflection of glass beads for traffic road stripe paints. Optical Materials 30 (2008) 1549-1554.

12 Carnaby B. Poor road markings contribute to crash rates. Australasian Road Safety Research Policing Education Conference. Wellington, New Zealand, 2005.

13 Horberry T., Anderson J., Regan MA. The possible safety benefits of enhanced road markings: a driving simulator evaluation. Transportation Research Part F: Traffic Psychology and Behaviour 9 (2006) 77-87.

14 Bahar G., Masliah M., Erwin T., Tan E., Hauer E. Pavement Marking Materials and Markers: Real-World Relationship Between Retroreflectivity and Safety Over Time. Contractor's Final Report for NCHRP Project 17-28 (2006).

15 Easa SM., Reed MJ., Russo F., Dabbour E., Mehmood A., Curtis K. Effect of increasing road light luminance on night driving performance of older adults. International Journal of Engineering and Applied Sciences 6 (2010) 41-48.

16 Żakowska L. Dynamic Road View Research for Road Safety and Aesthetics Evaluation. Journal for Geometry and Graphics 1 (1997) 51-57.

17 Żakowska L. The effect of environmental and design parameters on subjective road safety - a case study in Poland. Safety Science 19 (1995) 227-234.

18 Chameides W., Walker JC. A photochemical theory of tropospheric ozone. Journal of Geophysical Research 78 (1973) 8751-8760.

19 Lippmann, M. Health effects of tropospheric ozone. Environmental Science and Technology 25 (1991) 1954-1962.

20 OECD (Organisation for Economic Cooperation and Development). OECD Environmental Outlook to 2050: The Consequences of Inaction: The Key Findings on Health and Environment. Paris, 2012, http://www.oecd.org/environment/outlookto2050. Accessed 22.09.2015.

21 Godzik B. Ground level ozone concentrations in the Krakow region, southern Poland. Environmental Pollution 98 (1997) 273-280.

22 Leighton P. Photochemistry of air pollution. Academic Press, 1961, ISBN: 978-0124422506.

23 Crutzen PJ. Photochemical reactions initiated by and influencing ozone in unpolluted tropospheric air. Tellus 26 (1974) 47-57.

24 Carter WPL., Atkinson R. An experimental study of incremental hydrocarbon reactivity. Environmental Science and Technology 21 (1987) 670-679.

25 Carter WPL. Development of Ozone Reactivity Scales for Volatile Organic Compounds. Journal of Air and Waste Management Association 44 (1994) 881-899.

26 Martien PT., Harley RA., Milford JB., Russell AG. Evaluation of Incremental Reactivity and Its Uncertainty in Southern California. Environmental Science and Technology 37 (2003) 15981608 .

27 Ryerson TB., et al. Effect of petrochemical industrial emissions of reactive alkenes and NOx on tropospheric ozone formation in Houston, Texas. Journal of Geophysical Research: Atmospheres (1984-2012) 108 (2003) D8-1 - D8-24.

28 Carter WPL. Updated Maximum Incremental Reactivity Scale and Hydrocarbon Bin Reactivities for Regulatory Applications. California Air Resources Board Contract 07-339 (2009).

29 GDDKiA (Generalna Dyrekcja Dróg Krajowych i Autostrad / General Directorate for National Roads and Motorways), Warszawa. Authors' query through Public Information Bulletin, 2015.

30 Klösch H., Rairoux P., Weidauer D., Wolf J., Wöste L. Analysis of the tropospheric ozone dynamics by Lidar. Journal de Physique IV C4 (1994) 643-646.

31 Burghardt TE. Emissions aware. Intertraffic World (2016) 48.

32 Tebert C., Volz S., Müller W., Theloke J. Review of directive 2004/42/EC. Ökopol GmbH, Institute for Environmental Strategies, Hamburg, 2011. 


\title{
Wkład rozpuszczalników $\mathrm{z}$ farb drogowych do tworzenia się ozonu troposferycznego
}

\author{
Tomasz E. Burghardt ${ }^{1}$, Anton Pashkevich ${ }^{2}$, Lidia Żakowska ${ }^{2}$ \\ ${ }^{1}$ M. Swarovski GmbH, Industriestrasse 10, 3300 Amstetten, Austria, e-mail to- \\ masz.burghardt@swarco.com \\ ${ }^{2}$ Krakow University of Technology, Warszawska 24, 31-155 Krakow, \\ e-mailapashkevich@pk.edu.pl,lzakowsk@pk.edu.pl
}

Streszczenie: Rozpuszczalnikowe farby do poziomego znakowania dróg są znaczącym źródłem lotnych związków organicznych (Volatile Organic Compounds, VOC). VOC ulegając rozkładowi pod wpływem promieniowania słonecznego wpływają na powstawanie w troposferze ozonu, który jest związkiem chemicznym znacząco drażniącym system oddechowy i współodpowiedzialnym za powstawanie smogu. Wpływ poszczególnych VOC na tworzenie ozonu troposferycznego jest nierówny; wartości te zostały określone w maksymalnych przyrostowych reaktywnościach (Maximum Incremental Reactivities, MIR). MIR zostały użyte do obliczenia maksymalnego wpływu rozpuszczalników w farbach używanych w Polsce do znakowania dróg na tworzenie ozonu troposferycznego.

Na podstawie danych z roku 2014, ograniczających się jedynie do dróg zarządzanych przez Generalną Dyrekcję Dróg Krajowych i Autostrad (GDDKiA), emisja VOC z farb używanych do znakowania dróg dotyczyła ilości około $494838 \mathrm{~kg}$, co mogło prowadzić do produkcji około $1003187 \mathrm{~kg}$ ozonu.

Jeżeli wykorzystywane byłyby farby bez rozpuszczalników aromatycznych, oparte na estrach, jak to ma miejsce w Europie Zachodniej, emisje VOC nie uległaby zmianie, ale potencjał formowania ozonu zostałby ograniczony o 50-70\%. Jednakże, z punktu widzenia ochrony środowiska, najlepszym rozwiązaniem byłoby wykorzystywanie farb wodnych, wedle wymagań skandynawskich - wówczas możliwa byłaby eliminacja do $82 \%$ emitowanych VOC i ograniczenie do $95 \%$ powstałego ozonu troposferycznego.

Słowa kluczowe: znakowanie dróg, farby wodo-rozpuszczalne, farby rozpuszczalnikowe, ozon troposferyczny, VOC, bezpieczeństwo dróg, MIR, ochrona środowiska. 